Conway, W. S., K.C. Gross, C.D. Boyer, and C.E. Sams. 1988. Inhibition of Penicillin expansum polygalacturonase activity by increased apple cell wall calcium. Phytopathology 78:1052- 1055.

Conway, W. S., K.C. Gross, and C.E. Sams. 1987. Relationship of bound calcium and inoculum concentration to the effect of postharvest calcium treatment on decay of apples by Penicillium expansum. Plant Dis. 71:7880.

Conway, W.S. and C.E. Sams. 1983. Calcium infiltration of Golden Delicious apples and its effect on decay. Phytopathology 73:1068-1071.

Conway, WS. and C.E. Sams. 1985. Influence of fruit maturity on the effect of postharvest calcium treatment on decay of Golden Delicious apples. Plant Dis. 69:42-44,

DeLong, W.A. 1936. Variations in the chief ash constituents of apples affected with blotchy cork. Plant Physiol. 11:453-456.

Demarty, M., C. Morvan, and M. Thellier. 1984. Calcium and the cell wall. Plant Cell Environ. 7:441-448.

Drake, M., W.J. Bramlage, and J.H. Baker. 1979. Effects of foliar calcium on McIntosh apple storage disorders. Commun. Soil Sci. Plant Anal. 10:303309

Dyson, P.W. and J. Digby. 1975. Effects of calcium on sprout growth and subapical necrosis in Majestic potatoes. Potato Res. 18:290-305.

Faust, M. and C.B. Shear. 1972. Fine structure of the fruit surface of three apple cultivars. J. Amer. Soc. Hort. Sci. 97:351-355.

Glenn, G.M., B.W. Poovaiah, and H.P. Rasmussen. 1985. Pathways of calcium penetration through isolated cuticles of Golden Delicious apple fruit. J. Amer. Soc. Hort. Sci. 110:166-171.

Huber, D.M. 1981. The use of fertilizers and organic amendments in the contro of plant disease, p. 357-394. In: D. Pimentel (ed.). Handbook of pest management in agriculture. vol. I. CRC Press, Boca Raton, Fla

Maher, E.A., R.S. Livingston, and A. Kelman. 1986. Recognition of pectate lyase in western blots by monoclinal antibodies. Phytopathology 76:1101. (Abstr.)

Mason, J. L., B.G. Drought, and J.M. McDougald. 1974. Calcium concentration in apple fruit resulting from calcium chloride dips modified by surfactants and thickeners. HortScience 9: 122-1 23 .

Mason, J. L., J.J. Jasmin, and R.L. Granger, 1975. Softening of 'McIntosh' apples reduced by postharvest dip in calcium chloride solution plus thickeners. HostScience 10:524-525.

McGuire, R.G. and A. Kelman. 1984. Reduced severity of Erwinia soft rot in potato tubers with increased calcium content. Phytopathology 74:1250 1256.

McGuire, R.G. and A. Kelman. 1986. Calcium in potato tuber cell walls in relation to tissue maceration by Erwinia carotovora pv. atroseptica. Phytopathology 76:401-406.

Meyer, A. 1944. A study of the skin structure of Golden Delicious apples. Pmt. Amer. Soc. Hort. Sci. 45:723-727.

Pratt, A.A. and G.A. McIntyre. 1972. Effects of some divalent cations on the macerating activity of two pectic lyases produced by Pseudomonas fluorescent. Phytopathology 62:499. (Abstr.)

Preston, R.D. 1979. Polysaccharide formation and cell wall function. Annu. Rev. Plant Physiol. 30:55-78,

Reid, M.S. and C.A.S. Padfield. 1975. Control of bitter pit in apples with lecithin and calcium. New Zealand J. Expt. Agr. 7:379-381.

Sams, C.E. and W.S. Conway. 1984. Effect of calcium infiltration on ethylene production, respiration rate, soluble polyuronide content, and quality of 'Golden Delicious' apple fruit. J. Amer. Soc. Hort. Sci. 109:53-57.

Sams, C.E. and W.S. Conway. 1985. Effects of controlled atmosphere and calcium infiltration on decay of Delicious apples. Plant Dis. 69:747-750.

Sams, C.E. and W.S. Conway. 1987. Additive effects of controlled-atmosphere storage and calcium chloride on decay, firmness retention, and ethylene production in apples, Plant Dis. 71:1003-1005

Scott, K.J. and K.B.H. Wills. 1979. Effects of vacuum and pressure infiltration of calcium chloride and storage temperature on the incidence of bitter pit and low temperature breakdown of apples. Austral. J. Agr. Res. 30:917928

Sharples, R.O. and D.S. Johnson. 1977. The influence of calcium on senescence changes in apples. Ann. Appl. Biol. 85:450-453.

Shear, C.B. 1975. Calcium-related disorders of fruits and vegetables. HortScience 10:361-365

Simmons, K.E. and K.A. Kelling. 1987. Potato responses to calcium application on several soil types. Amer. Potato J. 64: 119-136.

Simmons, K. E., K.A. Kelling, R.P. Wolkowski, and A. Kelman. 1988. Effect of calcium source and application method on potato yield and cation composition. Agron. J. 80:13-21.

Smock, R.M. 1979. Controlled atmosphere storage of fruits, Hort. Rev. 1:301336.

Sommer, N. F., J.R. Buchanan, and R.J. Fortlage. 1977. Patulin in Ca-stored apples. Michigan State Univ. Hort. Rpt. 28, East Lansing, p. 2 12-221.

Tzeng, K. C., A. Kelman, K.E. Simmons, and K.A. Kelling. 1986. Relationship of calcium nutrition to internal brown spot of potato tubers and sub-apical necrosis of sprouts. Amer. Potato J. 63: 87-97.

Tzeng, K.C., R.G. McGuire, and A. Kelman. 1990. Resistance of tubers from different potato cultivars to soft rot caused by Erwinia carotovora subsp. atroseptica. Amer. Potato J. 67:287-305.

\title{
Global Regulation of Pectinases and Other Degradative Enzymes in Erwinia carotovora subsp. carotovora, The Incitant of Postharvest Decay in Vegetables
}

\author{
Arun Chatterjee, Hitoshi Murata, James L. McEvoy, and Asita Chatterjee \\ Department of Plant Pathology, University of Missouri, Columbia, MO 65211
}

Among the myriad bacteria present in our environment, only a small minority can cause diseases in plants, animals, or humans. It seems plausible that such bacteria have co-evolved with their hosts, acquiring traits that allow them to colonize host tissues and produce symptoms by triggering deleterious physiological responses or by destroying preformed structural components. An example of the latter is the elicitation of soft rot in a variety of plant tissues by a microbial consortium containing several Erwinia species as the primary component (Perombelon, 1987; Perombelon and Kelman, 1980). These

\footnotetext{
This manuscript is journal series no. 11,468 of the Missouri Agricultura Experiment Station. Research in our laboratories is supported by the National Science Foundation (grant DMB-9018733), the Science and Education Admin istration of the U.S. Dept. of Agriculture (grant 25846), a Collaborative Research Grant (no. 870022) from NATO International Scientific Exchange Programs, and a grant from the Food for the 21st Century program of the Univ. of Missouri Columbia. We thank D. W. Emerich and S .G. Pueppke for critically reading the manuscript.
}

bacteria produce an array of degradative enzymes that act on middle lamella and plant cell wall polysaccharides and proteins, weakening or solubilizing them, and ultimately causing cell separation and death.

Most commonly found enzymes in cultures of soft-rot bacteria or in rotted (i.e., macerated) tissues are pectinases, cellulases, proteases, and phospholipases (Bateman and Millar, 1966; Chatterjee and Vidaver, 1986; Collmer and Keen, 1986). Theoretical considerations alone imply that these enzymes, by acting on such structural components as pectin, cellulose, wall proteins (including hydroxyproline-rich glycoproteins), and membrane phospholipids, could inflict physiological and physical stress to which host tissues may ultimately succumb. Indeed, genetic and biochemical evidence indicates a crucial role for some of the pectinases in the elicitation of soft rot (Barras et al., 1987; Boccara et al., 1988; Collmer and Keen, 1986; Payne et al., 1987; Ried and Collmer, 1988; Roberts et al., 1986; Thum et al., 1987). In contrast, there is no convincing evidence for cellulase, protease, or phospholipase activities in the elicitation of tissue maceration by Erwinia spp., with the possible exception of E. carotovora subsp. 
carotovora (Jones) Bergey et al. (Ecc) (see "Note added in proof"). Therefore, at this juncture, it would be premature to summarily dismiss ancillary roles of these enzymes for the following reasons. 1) Since these enzymes have the potential to damage the cell wall and cell membranes, one could argue that they may augment the action of pectinases. 2) The degradative actions of cellulases and proteases may generate oligomers, dimers, or monomeric residues that the pathogens could assimilate. Thus, these depolymerizing enzymes, as components of catabolic pathways for assimilating polymeric substances, may contribute to pathogen fitness. 3) These enzymes, along with an assortment of pectinases, are consistently detected in macerated tissue, although the temporal sequence of their appearance is not known. Thus, unless proven otherwise, we have to entertain the possibility that deployment of these enzymes at some stage during pathogenesis is of consequence.

The degradative nature of these enzymes, their presence in macerated tissues, and their purported role in pathogenicity also raise the issue of coregulation of their production. The notion that the production of these enzymes may be subject to a common (i.e., global) regulatory control was first prompted by the pleiotropic nature of $E$. carotovora mutants isolated by Beraha and Garber (1971). By nitrosoguanidine mutagenesis, they isolated mutants deficient in extracellular pectate lyase (Pel), polygalacturonase (Peh), cellulase $(\mathrm{Ccl})$, protease (Prt), and phospholipase activities; subsequently, they obtained a one-step revertant that regained the ability to produce all of these enzymes. In Ecc strain 71, we also have isolated pleiotropic mutants using various transposons as well as the chemical mutagen, ethyl methanesulfonate (EMS). Properties of the mutants and the complementing DNA, discussed below, indicate the existence of a global regulatory network controlling extracellular enzyme production in the subspecies of E. carotovora.

Pectin lyase (Pnl), like Pel and endo-Peh, causes tissue maceration (Ishii, 1976; Tanabe and Kobayashi, 1987). Moreover, studies with fractionated Pels and Pnls indicate that a mixture of these enzymes elicits a more rapid substrate depolymerization than either enzyme alone (Tsuyumu et al., 1991). Thus, it is reasonable to suppose that Pnl may augment the tissue-macerating potential of Pel. This notion is supported by the observation that a Pnl mutant was severely attenuated in its ability to rot tobacco(Nicotiana tabacum L.) (Pirhonen et al., 1991).

Pnls produced by Erwinia spp. differ from the Pels in structural features and kinetic properties (Chatterjee et al., 1991a). A particularly remarkable difference lies in the mode of regulation. In most Erwinia spp., Pnl production, but not Pel, is induced after exposing bacteria to DNA-damaging agents such as UV light, mitomycin C, or nalidixic acid (Itoh et al., 1982; McEvoy et al., 1990; Tsuyumu and Chatterjee, 1984; Zink et al., 1985). Other traits that are generally coinduced with Pnl include bacteriocin (i.e., carotovoricin, Ctv) production, temperate bacteriophage induction, or cellular lysis (Lss) induction. Coregidation of these traits by DNA-damaging agents is reminiscent of SOS gene expression in E. coli (Little and Mount, 1982; Walker, 1984, 1987). (SOS gene expression is activated by agents and conditions that either damage DNA or interfere with DNA replication.) Indeed, we have determined that the activation of Pnl and Ctv production and Lss induction, like the activation of SOS responses, requires a RecA function (Zink et al., 1985). However, our observations, summarized below, also indicate that the stimulation of pnlA expression, the structural gene for pectin lyase, in response to DNAdamaging agents requires a transcriptional activator $(\operatorname{RdgB})$, which is in sharp contrast to the negative regulation of SOS genes. Since Rdg function is also required in Ctv production and Lss induction, we postulate that pnlA, ctv, and lss represent a subset of damage-inducible genes of Etc. Gene expression is controlled by RecA and Rdg.

\section{PLANT METABOLITE-ACTIVATED EXTRACELLULAR ENZYME PRODUCTION}

Previous studies had indicated that pectate, which markedly stimulated pectate lyase production in E. chrysanthemi Burkholder et al. strain EC16 (Chatterjee et al., 1979, 1985, 1991c), was only marginally effective in Ecc (Chatterjee et al., 199 lb). In E. chrysanthemi, genetic and physiological evidence has also indicated that intermediates of the pectate catabolic pathway (viz., keto-deoxyuronate, ketodeoxygluconate, or both) serve as inducers (Chatterjee et al., 1985; Collmer and Bateman, 1981, 1982; Condemine et al., 1986; Condemine and Robert-Boudouy, 1987; Hugouvieux-Cotte-Pattat and Robert-Boudouy, 1987). The lack of a significant effect of pectate in Ecc, therefore, raised the following possibilities. 1) The intracellular pool of ketodeoxyuronate remains low, and hence the pel genes are never fully induced when pectate is provided as the inducer source. 2) Conversely, the pool sizes of catabolic intermediates are high when pectate is the inducer source, and, as Tsuyumu (1977) postulated, the high levels cause catabolite repression" of Pel production. 3) It also is conceivable that a metabolize other than one derived from the pectate catabolic pathway is the "true" inducer for the Ecc enzymes. The findings discussed below support the last hypothesis.

In addition to sustaining a low Pel production level in Ecc, pectate did not significantly stimulate the production of other extracellular enzymes such as protease and cellulase, yet high levels of all these activities are consistently present in rotted tissue. These findings prompted the notion that plant tissues provide a signal(s) that simultaneously activates expression of genes specifying extracellular enzymes. To test this idea, we determined the levels of extracellular enzymes in AC5006, a LacZ derivative of the Ecc strain 71, grown in salts-yeast extract-glycerol (SYG) medium supplemented with pectate or extracts from celery(Apium graveolens L.) petioles, potato(Solanum tuberosum L.) tubers, or carrot (Daucus carota L.) roots. Specific activity of Pel was highest in SYG + celery extract, followed by SYG + potato extract, SYG + carrot extract, SYG + pectate, and SYG. Cel and Prt levels also were much higher in SYG + celery extract than in SYG or SYG + pectate. Stimulating extracellular enzyme production in Ecc with crude celery extract could be a response to separate signals, each activating a specific enzyme-producing system (i.e., Pel, Ccl, or Prt), or a response to a common signal that activates a global regulatory system specifically activating extracellular enzyme production.

The dogma that pectate is the universal inducer source for Pel production also is not supported by recent observations in $E$. chrysanthemi. For example, pelA expression is not stimulated to any significant extent by pectate in a derivative of E. chrysanthemi strain EC 16 (Chatterjee et al., 1991 c). In addition, Beaulieu and Van Gijsegem (1990) have provided genetic evidence for plant metabolize-activated pelA expression in E. chrysanthemi strain 3937. Kelemu and Collmer (1990) made a remarkable observation: in derivatives oE. chrysanthemi strain EC 16, wherein all the known pel genes (i.e., pelA, pelB, pelC, and pelE) had been inactivated (Ried and Collmer, 1988), a new set of Pel species was produced when bacteria were grown in the presence of plant cell wall. This phenotype apparently resulted from the activation of expression of normally silent pel genes.

Some of our recent observations with E. rapontici (Millard) Burkholder (Choi et al., 1991 ) are also similar to those of Kelemu and Collmer ( 1990). Erwinia rapontici strains do not produce Pel, Peh, or Prt in artificial media supplemented with pectate or pectin, yet they can macerate plant tissue, albeit at a slow rate. In extracts of rots caused by E. rapontici strains, we detected Pel activity that caused electrolyte loss and cell death in potato tuber tissue. Multiple Pel species were detected in rot extracts, and the enzyme profile was variable, depending on the plant tissue and bacterial strain. Plant cell wall preparations also activated Pel production in E. rapontici; however, the inducer activity was lost upon autoclaving. Since plant extracts that activated extracellular enzyme production in Ecc (see above) did not stimulate Pel production in E. rapontici, it is reasonable to assume that these bacterial systems respond to different plant signals. Further investigations should help identify signal(s) activating enzyme production in $E$. raponici and the regulatory gene(s) responding to plant signal(s).

\section{GLOBAL REGULATION OF EXTRACELLULAR ENZYME PRODUCTION}

Genetic and physiological studies have unraveled two global systems controlling extracellular pectate lyase production and protease and cellulase production in Ecc: one requires the functions of the genes designated as aep (activator of extracellular protein production) 
characterization of an Erwinia carotovora subsp. carotovora pectin lyase gene that responds to DNA-damaging agents. J. Bacteriol. 172:3284-3289.

McEvoy, J. L., K.K. Thum, and A.K. Chatterjee. 1987. Expression of the E. coli lexA $A^{+}$gene in Erwinia carotovora subsp, carotovora and its effect on production of pectin lyase and carotovoricin. Fed. European Microbiol. Soc. Microbiol. Lett. 42:205-208.

Mount, M.S., P.M. Berman, R.P. Mortlock, and J.P. Hubbard. 1979. Regulation of endopolygalacturonate transeliminase in an adenosine 3',5'-cyclic monophosphate-deficient mutant of Erwinia carotovora. Phytopathology 69:117-120.

Murata, H., J.L. McEvoy, A. Chatterjee, A. Collmer, and A.K. Chatterjee. 1991. Molecular cloning of an aepA gene that activates production of extracellular pectolytic, cellulolytic, and proteolytic enzymes in Erwinia carotovoia subsp, carotovora. Mol. Plant-Microbe Interactions 4:239246.

Pastan, I. and S. Adhya, 1976. Cyclic adenosine 5'-monophosphate in Escherichia coli. Bacteriol. Rev. 40:527-551.

Payne, J. H., C. Schoedel, N.T. Keen, and A, Collmer, 1987. Multiplication and virulence in plant tissues of Escherichia coli clones producing pectate lyase isozymes PLb and PLe at high levels and of an Erwinia chrysanthemi mutant deficient in PLe. Appl. Environ. Microbiol. 53:23 15-2320.

Perombelon, M.C.M. 1987. Pathogenesis by pectolytic Erwinias, p. 109-120. In: E.L. Civerolo, A. Collmer, R.E. Davis, and A.G. Gillaspie (eds.). Plant pathogenic bacteria. Martinus Nijhoff, Dordrecht,

Perombelon, M.C.M. and A. Kelman. 1980. Ecology of the soft rot Erwinias. Annu. Rev. Phytopathol. 18:361-387.

Pirhonen, M., H. Saarilahti, M-B. Karlsson, and E.T. Palva. 1991. Identification of pathogenicity determinants of Erwinia carotovora subsp. carotovora by transposon mutagenesis. Mol. Plan-Microbe Interactions 4:276-283.

Ried, J.L. and A. Collmer, 1988. Construction and Characterization of an Erwinia chrysanthemi mutant with directed deletions in all of the pectate lyase structural genes. Mol. Plant-Microbe Interactions 1:32-38.

Roberts, D. P., P.M. Berman, C. Allen, V.K. Stromberg, G.H. Lacy, and M.S. Mount. 1986. Requirement for two or more Erwinia carotovora subsp. carotovora pectolytic gene products for maceration of potato tuber tissue by Escherichia coli, J. Bacteriol. 167:279-284.

Saarilahti, H. T., P. Heino, R. Pakkanen, N. Kalkkinen, L Palva, and E.T, Palva. 1990. Structural analysis of the pehA gene and characterization of its protein product, endopolygalacturonase, of Erwinia carotovora subspecies carotovora. Mol. Microbiol, 4: 1037-1044.

Tanabe, H. and Y. Kobayashi. 1987, Plant-tissue maceration caused by pectinolytic enzymes from Erwinia spp, under alkaline conditions. Agr. Biol. Chem, 51:2845-2846.

Thum, K. K., F. Barras, Y. Kegoya-Yoshino, and A.K. Chatterjee. 1987. Pectate lyase of Erwinia chrysanthemi: PelE-like polypeptides and pelE homologous sequences in strains isolated from different plants. Physiol. Mol. Plant Pathol. 31:429439.

Tsuyumu, S. 1977. Inducer of pectic acid lyase in Erwinia carotovora. Nature 269:237-238.

Tsuyumu, S. and A.K. Chatterjee, 1984. Pectin lyase production in Erwinia chrysanthemi and other soft-rot Erwinia species. Physiol. Plant Pathol. 24:291-302.

Tsuyumu, S., M, Miura, and S. Nishino. 1991. Distinct induction of pectinases as a factor determining host specificity of soft rot Erwinia,p.3141, In: S.S. Patil, S. Ouchi, D. Mills, and C. Vance (eds.). Moleculm strategies of pathogens and host plants, Springer-Verlag, Berlin.

Ullmann, A. and A. Danchin. 1983. Role of cyclic AMP in bacteria, p. 1-53. In: P. Greengard and G.A. Robison (eds.). Advances in cyclic nucleotide research. vol. 15. Raven Press, New York.

Walker, G.C. 1984. Mutagenesis and inducible responses to deoxyribonucleic acid damage in Escherichia coli. Microbiol. Rev. 48:60-93.

Walker, G.C. 1987. The SOS response of Escherichia coli, p. 13461357. In: F.C. Neidhardt, J.L. Ingraham, K.B. Low, B. Magasanik, M. Schaechter, and H.E. Umbarger (eds.). Escherichia coli and Salmonella typhimurium. vol. 2. Amer. Sot. Microbial., Washington, D.C.

Zink, R. T., J,K. Engwall, J.L. McEvoy, and A.K. Chatterjee. 1985. recA is required in the induction of pectin lyase and carotovoricin in Erwinia carotovora subsp. carotovora. J. Bacteriol. 164:390-396.

\title{
Integrating Biological Control into Postharvest Disease Management Strategies
}

\author{
Rodney G. Roberts ${ }^{1}$ \\ U.S. Department of Agriculture-Agricultural Research Service, Tree Fruit Research Laboratory, \\ Wenatchee, WA 98801
}

Technological advances in regular (cold, ambient atmosphere; RA) and controlled-atmosphere (CA) storage, computerized sorting and grading, and mechanical processing and packing of apple (Malus domestics Borkh.) and other tree fruits allow the industry to harvest, store, and market large crops efficiently. Unfortunately, the same postharvest diseases that occurred 60 years ago still cause economic losses (Baker and Heald, 1932; Heald and Ruehle, 1931), although perhaps not to the same extent. Blue mold (caused by Penicillium expansum Link), gray mold (caused by Botrytis cinerea Pers.:Fries), and mucor rot (caused by Mucor piriformis E. Fisch.) cause economic losses for growers and packers of apples and pears (Pyriscommunis L.) every year. Bull's eye rot of apple and pear\{ caused byCryptosporiopsis malicorticis (Cordl.) Nann. [Pezictla malicorticis (H. Jacks.) Nann.] \} causes episodic losses when environmental conditions at petal fall and harvest are conducive to infection. Losses caused by these diseases historically have been managed primarily by applying fungicides, although interest in integrated postharvest disease control has increased recently (Willett et al., 1989). Several biological and regulatory factors have spurred development of alternative disease management approaches. Development of resistance in pathogens to fungicides, particularly to benzimidazoles (Rosenberger and Mayer, 1979; Spotts and Cervantes, 1986), has limited or eliminated the effectiveness of these chemicals for postharvest use in some areas of the United States. Some countries that import fruit from the United States do not

Mention of a trade name, proprietary product, or specific equipment does not constitute a guarantee or warranty by the U.S. Dept. of Agriculture and does not imply its approval to the exclusion of other products that may be suitable. 'Supervisory Research Plant Pathologist. allow residues of some fungicides, such as $\mathrm{N}-[($ trichloromethyl)thio]4-cyclohexene- 1,2-dicarboximide (captan). Other countries, such as Japan, allow no residues of any postharvest fungicide on fruit imported from the United States. Additionally, emotional debates over chemical residues in food products (National Research Council, 1987), highlighted by the Alar (n-dimethylamino succinamic acid) controversy, have made some chemical companies reluctant to pursue re-registration of effective materials. Developing non- or reduced-chemical postharvest disease management strategies has become an economic imperative rather than an option.

Biological control of plant disease is not anew concept, but efforts to apply biological control theory to postharvest diseases of fruit are recent, as indicated by the scarcity of references to postharvest biocontrol in general texts and in reviews of biocontrol of plant pathogens (Baker and Cook, 1982; Cook and Baker, 1983; Lewis and Papavizas, 1991). Promising postharvest biocontrol agents have been identified, and significant efforts are being made to develop them for commercial use. Pioneering work by Tronsmo and Raa (1977) investigated the use of the filamentous fungus Trichodermapseudokoningii Rifai as an antagonist against gray mold (caused by B. cinerea) of strawberry (Fragaria $\times$ ananassa Duch.). Biocontrol yeasts, including Acremonium breve (Sukapure \& Thirumalachar) W. Gains (Janisiewicz, 1988), Candida guilliermondii (Castellani) Langeron \& Guerra [as Debaryomyces hansenii (Zopf) Lodder \& Krieger-van Rij] (Chalutz and Wilson, 1990; McLaughlin et al., 1990), Hanseniaspora uvarum (Niehaus) Shehata, Mrak \& Phaff (McLaughlin et al., 1989), Cryptococcus laurentii (Kuff.) C.E. Skinner, C. flavus (Saito) Phaff \& Fell, and C. albidus var. aerius (Saito) Phaff \& Fell (Roberts, 1990a, 1990b, 199 1), are effective against various postharvest decays in several fruits 